\title{
Svenska judars berättelser om flyktingar, överlevande och hjälpverksamheter under och efter Förintelsen
}

\author{
Malin Thor Tureby
}

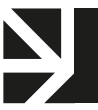

VERTAISARVIOITU

KOLLEGIALT GRANSKAD

PEER-REVIEWED

www.tsv.fi/tunnus

DOI: https://doi.org/10.30752/nj.90024

\begin{abstract}
Swedish Jews' supposed inactivity over Europe's persecuted Jews during the Holocaust has been a prevalent discourse during the post-war period. This article ponders the origins of that discourse and how it affects how and what Swedish Jews narrate about aid and relief work, and Jewish refugees and survivors, when recounting their memories from the I930s and I940s. This investigation also examines how previous research has addressed and represented the aid efforts of the Jewish minority in Sweden and discusses what new empirical knowledge about Swedish Jewish aid and relief work during the Holocaust we can ascertain by using oral history. Hence, it is also a contribution to the ongoing debate in the research field of 'refugee studies', initiated by the historians Philip Marfleet and Peter Gatrell, who emphasise both the importance of working with historical perspectives and asking questions about the sources at the disposal of historians and what sources they choose to work with when writing about aid, relief work and refugees.
\end{abstract}

Det fanns mycket att göra för att hjälpa flyktingar och krigets offer, men jag kan inte finna att jag gjort mycket. Efter min faders död blev det mycket att göra såväl på kontoret som hemma. Enligt judisk sed vilade ansvaret för släkten på den äldste sonen. Det fanns många släktingar på min faders sida och även på min moders sida. Ansvaret för dem fick jag övertaga. [Mannen har tidigare skrivit om att hans mammas släktingar flytt från Norge till Sverige och att han har försörjningsansvaret för dem samt för att skicka gåvopaket till de släktingar som inte lyckades fly, blev deporterade, och befann sig i nazisternas koncentrationsläger.] [...] Kontoret, min egen familj och släkt - familjen tog all min tid. Det fanns ingen tid över. Det blev således ingen tid för det judiska. $\left(\mathrm{D}_{375: 46)}\right.$
I detta korta utdrag från en skriftlig levnadsberättelse, författad av en man bosatt i Göteborg under I 940-talet, väcks flera frågor som föreliggande artikel vill belysa angående de svenska judarnas engagemang för och hjälp till Europas förföljda judar. Citatet väcker frågor om vad som är att betrakta som judisk hjälpverksamhet? Vilken hjälp som organiserades, av vem, för vilka, var och varför? Citatet belyser ett dåligt samvete eller ett svar på den outtalade frågan om varför han inte gjorde mer för att hjälpa Europas förföljda judar, flyktingarna och de överlevande när de väl kommit till Sverige; en fråga som återkommer i flera av de insamlade berättelserna som idag utgör samlingen "Judiska minnen" vid Nordiska museet. ${ }^{1}$

1 Artikeln är författad inom ramen för forskningsprojektet "Judisk och kvinna. 
De svenska judarnas förmenta passivitet i relation till Europas förföljda judar har varit en tongivande diskurs under efterkrigstiden. Statsvetaren Svante Hansson fick därför år 2000 i uppdrag av den judiska församlingen i Stockholm att skriva en vitbok om den judiska församlingens i Stockholm agerande under kriget. Anledningen var att:

Flera överlevande fortsätter (50 år + senare) att anklaga Judiska Församlingen för att den inte gjorde tillräckligt under och efter kriget. Beskyllningar om att det tom var församlingsledningens i Stockholm fel att inte flera judar släpptes in förs också fram. (Hansson 2004: I6)

Inom ramen för sitt uppdrag genomförde Svante Hansson en intervjuundersökning för att försöka få ett bättre grepp om skälen till de överlevandes oupphörliga anklagelser om att församlingen inte gjorde tillräckligt under och efter kriget. Hansson skriver att han i första hand ville "samla in uppgifter, berättelser och dokument om de intervjuades konkreta erfarenheter av Mosaiska Församlingens flyktingarbete i förhoppning att därav kunna dra slutsatser om hur deras attityder till Församlingen som centrum för judiskt liv uppstod och utvecklades" (Hansson 2004: 20).

I föreliggande artikel vänder jag på perspektivet. Genom en närläsning av samtliga av de 50 levnadsberättelser från personer som kategoriseras som svenskfödda judar i samlingen”Judiska minnen" undersöker jag hur de svenska judarna berättar om sina erfarenheter och minnen av hur det var att leva i Sverige under andra världskriget och i skuggan av

Intersektionella och historiska perspektiv på judiska kvinnors liv i Sverige under I900- och 2000-talen". Projektet är finansierat av Vetenskapsrådet, Dnr. 2016-03983.
Förintelsen samt hur och vad de berättar om den "judiska hjälpverksamheten" och sina möten med flyktingar och överlevande.

Det övergripande syftet med föreliggande artikel är att reflektera över vilken ny kunskap om den judiska hjälpverksamheten i Sverige i skuggan av Förintelsen vi kan nå genom att använda oss av oral history, i denna undersökning med det insamlade materialet från personer kategoriserade som svenskfödda judar i samlingen "Judiska minnen" som empiriskt exempel. Därmed anknyter artikeln även till forskningsfältet refugee studies och framförallt den inriktning inom fältet som företräds av historikerna Philip Marfleet och Peter Gatrell som framhåller dels vikten av att arbeta med historiska perspektiv inom fältet, dels betydelsen av att arbeta med olika arkiv och material för att möjliggöra analyser som inte enbart fokuserar på staters eller hjälporganisationers perspektiv och agerande, utan även flyktingarnas och andra aktörers perspektiv, initiativ och handlingar (Gatrell 2013, 20I 7; Marfleet 2007; se även Stone 2018).

\section{Samlingen "Judiska minnen" och tidigare forskning om det judiska hjälparbetet}

När Svante Hansson i början av 2000-talet fick i uppdrag av församlingen att utreda dess agerande under andra världskriget, hade inte någon svensk historiker intresserat sig för den svenska judiska minoritetens agerande eller erfarenheter under Förintelsen. De hade forskat om Sverige under andra världskriget, men främst med fokus på neutralitets- och säkerhetspolitiken. Senare har även den svenska flyktingpolitiken undersökts.

Under 2oro-talet blev församlingens i Stockholm agerande än mer utforskat i Pontus Rudbergs avhandling, The Swedish Jews and the Victims of Nazi Terror, 1933-1945 (201 5), en forskningsinsats som kompletterar Hanssons resultat. Därtill finns ett antal mindre 
studier av hjälpverksamheten inom ramen för de mosaiska församlingarna i Kalmar och Norrköping (Thor 2006, 2008, 2010). Det saknas ännu studier av verksamheten inom församlingarna i Göteborg och Malmö. Därtill föreligger fortfarande inte några ingående studier om mottagningen och integrationen av såväl flyktingarna som de överlevande i det svenska samhället. Några få studier med socialhistoriskt perspektiv eller med utgångspunkt i oral history publicerades på I990-talet som diskuterar flyktingarnas och de överlevandes erfarenheter, perspektiv och möjligheter att integreras i Sverige (Lomfors i996; Olsson r 995; Sterner Carlberg r 994; se även Thor 2005). Forskning som placerar "flyktingarna" eller"de överlevande" i centrum och som söker att förstå dem som någonting mer än "flyktingar" och "överlevande", med ett liv före, under och efter Förintelsen är således mycket eftersatt i Sverige. ${ }^{2}$

I en amerikansk kontext har berättelser om judiskt hjälparbete använts för att bygga upp och bekräfta en judisk minoritetsidentitet och gemenskap samt närvaro och tillhörighet i majoritetssamhället (se t.ex. Bergoffen 20 i 6; Sarna I 995). Några liknande berättelser har knappt förekommit i Sverige. Det finns ett par korta redogörelser i församlingshistorikerna från Göteborg och Malmö (se t.ex. Rubinstein r 97I; Segerstedt Wiberg 1980). Inga Gottfarbs bok Den livsfarliga glömskan (1986), som beskriver hennes arbete med judiska flyktingar och överlevande under och efter kriget, utgör ett sällsynt undantag. Det finns således ytterst få berättelser eller redogörelser författade om eller av de svenska judarna om arbetet för Europas judar under

2 Det pågår dock sådan forskning.

Doktorand Victoria Van Orden Martinez vid Linköpings universitet arbetar med en avhandling med arbetstiteln "Afterlives: Histories of Women Concentration Camp Survivors in Sweden". kriget. Även tidskrifterna Judisk krönika och Judisk tidskrift innehåller få reportage eller artiklar om flyktingar, judisk hjälpverksamhet om hur de svenska judarna sökte hjälpa Europas förföljda judar under r930- och r940-talen. Denna avsaknad av ett offentligt narrativ om det judiska hjälparbetet bestod även under det första decenniet efter kriget. De personer och de hjälpverksamheter som lyftes fram i dessa tidskrifter som hjältar var snarare den svenske konungen, Folke Bernadotte och Raoul Wallenberg (Thor Tureby 2013b, 2020uu). Sannolikt är denna frånvaro av offentliga berättelser om det svenskjudiska hjälparbetet i samtiden en bidragande förklaring till att de svenska judarnas förmenta passivitet, deras föregivet bristande hjälp till Europas judar debatterades $\mathrm{i}$ en internationell och nationell inomjudisk kontext direkt efter andra världskriget (Thor 2008: I 79).

Den judiska hjälpverksamheten synliggjordes likafullt i Församlingsblad för Mosaiska församlingen i Stockholm. Detta var emellertid en publikation som främst riktade sig till medlemmarna av församlingen i Stockholm, varför den sannolikt inte lästes vare sig av flyktingar, överlevande, icke-judar eller företrädare för internationella judiska hjälporganisationer. I augustinumret I 947 redogjordes i Församlingsbladet för en rad verksamheter som församlingen bidragit till. Numret översattes även till engelska, förmodligen för att bemöta den kritik som riktats mot församlingen i Stockholm,från såvälöverlevande som företrädare för den amerikanska judenheten, om att den inte gjort eller gjorde tillräckligt för flyktingarna och de överlevande. Trots temanumret och kontinuerliga reportage om olika hjälpverksamheter i Församlingsbladet fortlevde diskursen om de svenska judarnas passivitet under efterkrigstiden. Avsaknaden av berättelser i den svenska och svenskjudiska offentligheten om alla de aktioner och 
verksamheter som genomfördes av de judiska församlingarna, föreningarna och individerna var således påtaglig redan under I930- och I 940-talen, men även under decennierna som följde (Thor Tureby $2020 u u$ ).

Frånvaron av offentliga narrativ kan även relateras till att flera initiativ till forskning om Förintelsen, den judiska minoriteten i Sverige och insamlingar av överlevandes berättelser förvisso har initierats under årens lopp. Utebliven långsiktig finansiering ledde dock i flera fall till att projekten aldrig realiserades eller lades ned, varför få av initiativen resulterade i några större forskningsprojekt eller publikationer. ${ }^{3}$ Redan r 945 när de befriade från koncentrationslägren kom till Sverige initierades till exempel två stora intervjuoch insamlingsprojekt. I Lund initierades en insamling som resulterade i 500 insamlade berättelser, så kallade vittnesprotokoll, som skulle användas vid framtida rättegångar mot de nazistiska förbrytarna, men även som källmaterial i framtida historisk forskning. Samtidigt inleddes i Uppsala ett annat projekt som ledde till 600 insamlade intervjuer och enkäter. Syftet med insamlingen i Uppsala var inte att skapa ett historiskt källmaterial, snarare att skapa ett material

3 Svante Hansson som fick i uppdrag att skriva församlingens vitbok forskade redan på i 970-talet om den mosaiska församlingens agerande. Han handledde två studerande som skrev uppsatser på grundval av det material som Hansson samlat in (bland annat intervjuer med personer som organiserade olika hjälpverksamheter inom eller i samarbete med församlingen i Stockholm). Anna Besserman skrev om församlingen och flyktingarna i uppsatsen "Svartingstorp I936-I 940. Kibbutz eller lantbruksskola?" och Ove Kennerberg lade fram två uppsatser: "Svenska judars reaktion på den tyska nazismen I 933-I935" och "Mosaiska församlingens i Stockholm flyktingverksamhet I 933-Kristallnatten I 938 ".

Se Hansson 2004: 24-25. för större kvantitativa socialpsykologiska undersökningar. Något sådant projekt blev aldrig av (Thor Tureby 2020). I stället pub1icerades boken, De dödsdömda vittnar (Tegen och Tegen r 945). Boken innehåller ett urval av de insamlade vittnesmålen. Vad som finns kvar av det insamlade materialet finns idag arkiverat i Gunhild Tegens arkiv vid Uppsala universitetsbibliotek.

Det finns en koppling mellan samlingen "Judiska minnen" vid Nordiska museet i Stockholm och Gunhild Tegens samling. När författaren Pia-Kristina Garde under I 980talet började att efterforska vad som hade hänt de kvinnor som intervjuades 1945 insåg hon att inte något större arbete hade gjorts om dem i Sverige. Gardes anmärkningsvärda forskningsinsats resulterade senare i två böcker (Garde 2004, 2008), men även initieringen av vad som skulle komma att bli samlingen "Judiska minnen". I början av I 990-talet var Garde anställd vid biblioteket på Nordiska museet. Hon föreslog då att Nordiska museet skulle intervjua de överlevande som kom till Sverige I 945, men även dem som tog emot dem. Initieringen av insamlingen "Judiska minnen" kan också placeras i ett bredare internationellt sammanhang. Arkiverad korrespondens visar att personalen som var anställd i projektet interagerade med andra minnesinstitutioner som arbetat med att bygga upp liknande samlingar, främst i USA och Israel. Dessa kontakter påverkade med största sannolikhet hur insamlingsprocessen i Sverige utformades. Insamlingen som inleddes på Nordiska museet 1994 med dess fokus på personliga minnen och erfarenheter från och om Förintelsen har en inriktning som var relativt ny i ett svenskt sammanhang. Samlingen på Nordiska museet är därmed snarare relaterad till hur insamlingar av och forskning om berättelser från de överlevande har utvecklats inom det internationella forskningsfältet Holocaust studies i andra länder, än 


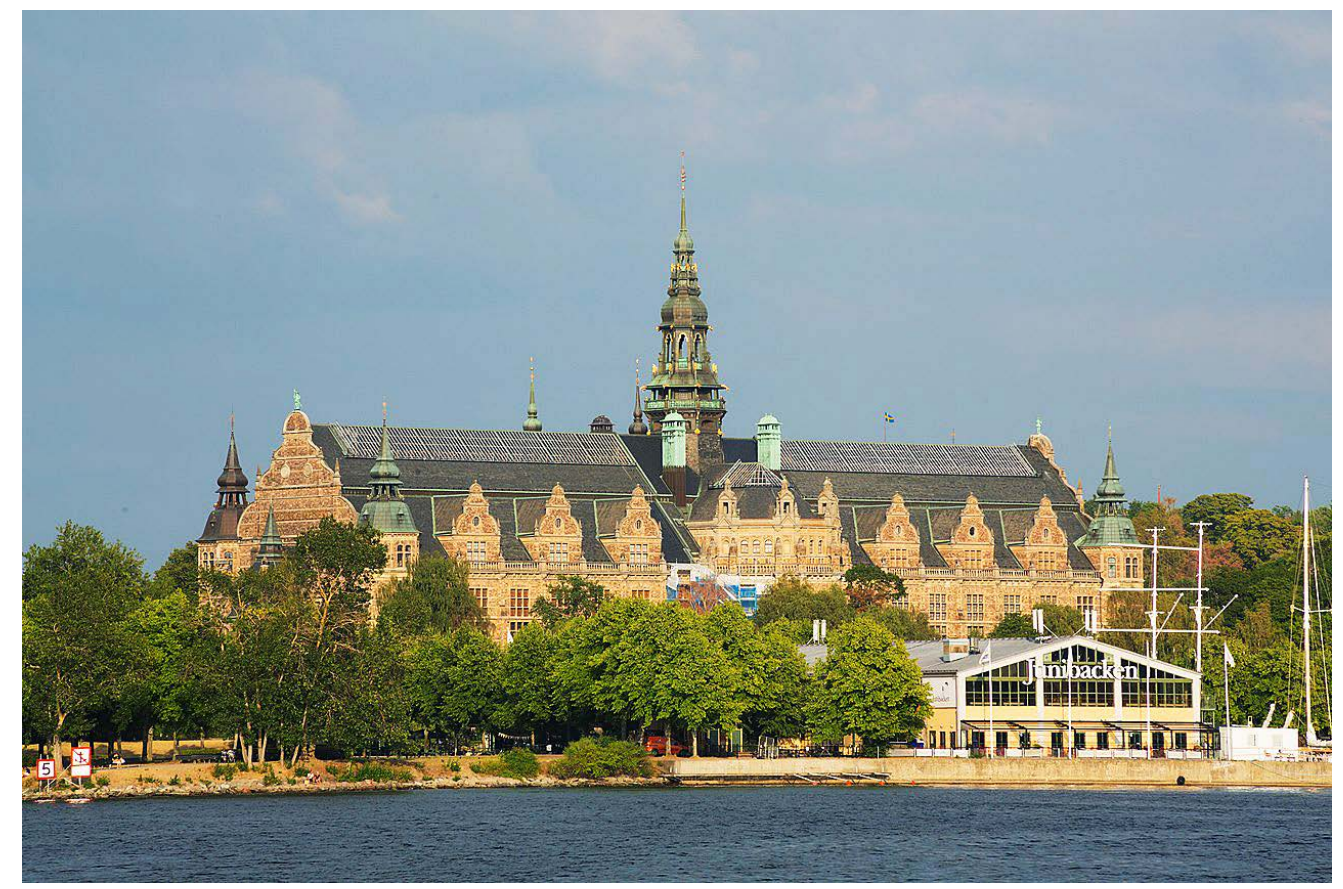

Nordiska museet, Stockholm. Liberaler Humanist, Wikimedia Commons, CC BY-SA 3.0.

till tidigare samlingar och publicerad forskning om Förintelsen i en svensk kontext.

Samlingens inriktning och innehåll är även starkt präglad av att insamlingen och arkiveringen gjordes vid Nordiska museet, vilket jag har påtalat $\mathrm{i}$ tidigare publikationer om dokumentations- och arkiveringsprocessen av "Judiska minnen". Jag redogör därför inte för initieringen, insamlingen och arkiveringen av materialet här utan hänvisar till dessa texter (Thor Tureby 2013a, 2019). Nordiska museet och dess insamlings- och arkiveringspraktiker har fått ett stort genomslag i det insamlade och arkiverade materialet. Dokumentationsmetoder är aldrig neutrala. Sättet att samla in och arkivera materialet skapar en speciell typ av levnadsberättelse och Nordiska museet har därmed varit med om att forma hur judiska liv berättades inom ramen för insamlingen "Judiska minnen". Flera av dem som bidragit till samlingen berättar t.ex. om föräldrars och mor- och farföräldrars yrken, liv, traditioner och högtider, frågor som ofta ingår vid insamlingar vid Nordiska museet. Samlingen förbinds därmed med andra samlingar vid institutionen, både vad gäller arkiveringsprocess och innehåll."Judiska minnen" innehåller därmed flera olika beskrivningar av hur det var att leva som jude och judinna i Sverige under andra världskriget och Förintelsen. I föreliggande text är det främst hur personer som kategoriseras som svenskfödda judar i samlingen berättar om sina erfarenheter och minnen av hur det var att leva i Sverige under andra världskriget och Förintelsen och deras minnen från arbetet för och möten med flyktingar och överlevande som undersöks. Intervjuerna och de insamlade berättelserna som idag utgör samlingen "Judiska minnen" har en specifik tillkomstkontext, vilket nämnts ovan. Därjämte är det viktigt att beakta att samlingen skapades under åren r 994-I 998 när enbart ett fåtal undersökningar förelåg om de judiska flyktingarna och de överlevande i Sverige och inte någon publicerad vetenskaplig 
studie som undersökt den judiska minoritetens i Sverige hjälpverksamheter förelåg. De levnadsberättelser som analyseras i föreliggande text samlades in under r990-talet och förhåller sig därmed till de diskurser om det svensk-judiska hjälparbetet som fanns vid denna tidpunkt i Sverige. Jag undersöker således inte enbart de insamlade levnadsberättelserna i samlingen "Judiska minnen" för att nå ny kunskap om den svensk-judiska verksamheten för Europas förföljda judar, utan studerar även hur berättarna förhåller sig till diskursen kring de svenska judarna och hjälpverksamheten under I990-talet.

\section{Berättarna: de intervjuade och intervjuarna}

Samlingen består av ca 400 levnadsberättelser, varav 50 är från personer som kategoriseras som "svenskfödda". Det är dessa 50 berättelser, varav 24 är transkriberade intervjuer och 26 är skriftliga levnadsberättelser, som utgör det empiriska underlaget i föreliggande artikel. ${ }^{4}$ Framställningen utgår från fyra intervjuer som är utvalda därför att jag ville arbeta med intervjuer med såväl män som kvinnor, men även från olika platser i Sverige. Efter att ha läst igenom ett flertal transkriberade intervjuer, insåg jag även att det spelade en mycket stor roll vem som hade intervjuat de olika personerna för hur och vad som sades under intervjuerna. De utvalda transkriberade intervjuerna utgör således även exempel på olika intervjuares bidrag till hur berättelserna i samlingen har utformats. Av forskningsetiska skäl anonymiseras samtliga berättare i enlighet med Nordiska museets regler för hur det insamlade materialet får användas. ${ }^{5} \mathrm{De}$

4 För en utförlig beskrivning av dessa 50 berättelsers form och innehåll se Thor Tureby 2019a: I 23.

5 Det är dock högst sannolikt att det är tämligen uppenbart vem som intervjuas för den som har kunskap om eller tillhör den intervjuade har fått pseudonymerna: Anna, Barbro, Carl och David.

Skälen till att de fyra personer, vars berättelser utgör stommen i föreliggande framställning, intervjuades inom ramen för insamlingen "Judiska minnen" skiljer sig åt. Anna hörde själv av sig till projektet och ville bli intervjuad eftersom hon inte orkade skriva ner sina minnen utan hellre ville bli intervjuad ( $\left.\mathrm{D}_{375: 22 \mathrm{I}}\right)$. Den andra av de intervjuade kvinnorna, Barbro, tillfrågades om hon ville ställa upp på en intervju eftersom det sedan tidigare var känt att hon hade varit mycket engagerad i det judiska hjälparbetet under kriget (D375:224). Carl kontaktades för en intervju med anledning av att han hade varit mycket engagerad i församlingarna i Lund och Malmö och senare även i det judiska hjälparbetet som organiserades av församlingen i Stockholm ( $\mathrm{D}_{375: 259}$ ). David tillfrågades därför att han var en känd kulturpersonlighet i I990-talets Sverige (D 375:232). Annas, Barbros, Carls och Davids berättelser utgör strukturen i föreliggande framställning. Jag kommer dock löpande att hänvisa till andra berättelser från samlingen för att låta flera röster tala och därmed fördjupa förståelsen eller problematisera de berättelser som återfinns i de fyra utvalda intervjuerna.

Av de transkriberade intervjuerna, som har närlästs och som strukturerar framställningen i föreliggande text, tillkom enbart en på grund av att personen, Anna, själv kontaktade Nordiska museet. De övriga tre personerna kontaktades av insamlingsprojektet för

judiska minoriteten i Sverige. En fullständig anonymisering är generellt omöjlig att genomföra och ibland är det inte önskvärt att anonymisera personer i kvalitativa studier eller oral history. Även den forskningsetiska lagstiftningen inverkar således på hur, vilken och vems historia som vi kan skriva. Se Thor Tureby 20 I9c: 17-29. 


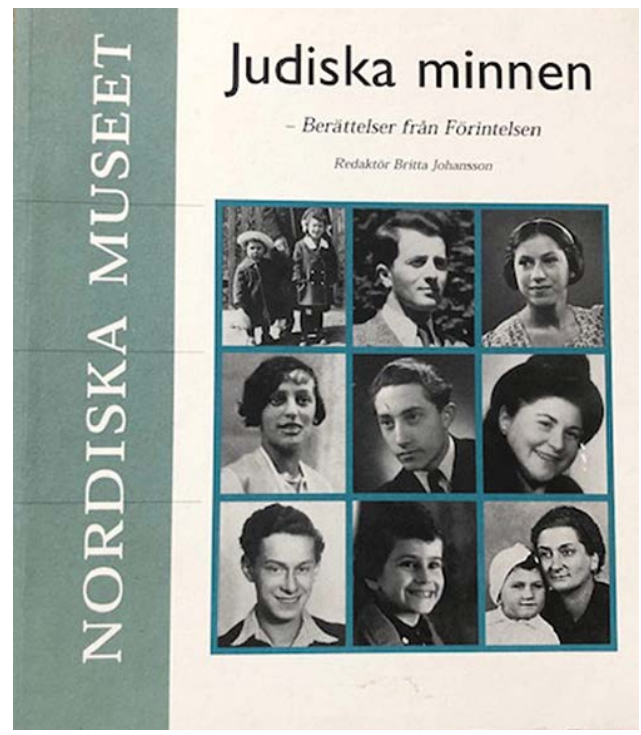

Boken Judiska minnen. Berättelser från Förintelsen innehåller några redigerade berättelser från samlingen "Judiska minnen" som samlades in vid Nordiska museets arkiv 1994-1998.

att intervjuas. Barbro och Carl tillfrågades eftersom de var centrala personer i hjälparbetet och det judiska livet i Stockholm respektive södra Sverige. David intervjuades främst, som nämnts ovan, därför att han var en känd kulturpersonlighet i i 990-talets Sverige. Hans far var mycket involverad i det judiska livet och flyktingmottagningen i Stockholm under I930- och r 940-talen, vilket dock inte anges som ett motiv för varför David intervjuades. Han får inte heller några frågor om fadern under intervjun. Intervjuerna genomfördes av tre olika intervjuare. I intervjun med Barbro, som gjordes av projektledaren Ingrid Lomfors, deltog även Britta Johansson som observatör utan att delta i samtalet. Britta Johansson intervjuade Anna och Carl och Charlotte Urwitz genomförde intervjun med David. Ingrid Lomfors och Charlotte Urwitz har en judisk identitet, vilket framgår under flera intervjuer i samlingen. Britta Johansson har en icke-judisk bakgrund, vilket gör henne en aning osäker inför en del intervjusituationer, vilket hon också redogör för på ett ingående och reflekterande sätt (se

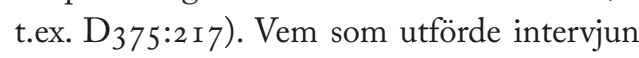
spelar således en stor roll för hur och vad som berättas under intervjutillfället.

\section{Berättelser om händelseutvecklingen i Europa och livet i Sverige under kriget}

När de svenska judarnas agerande och förmenta passivitet under Förintelsen har diskuterats och debatterats har det sällan gjorts från i framlänges perspektiv, utan i ett retrospektivt perspektiv. Ett sådant förhållningssätt utgår från ett facit, där vi vet att Sverige aldrig ockuperades av nazisterna och att de svenska judarna därmed aldrig deporterades eller stod under hot att deporteras. Även det insamlade materialet som utgör"Judiska minnen" är ett retrospektivt material. Det vill säga personer söker dra sig till minnes hur och vad de tänkte, kände och gjorde i olika situationer. När Anna får frågan om hennes föräldrar planerade en eventuell flykt eller pratade om rädsla för [att nazisterna även skulle ockupera Sverige] svarar hon mycket svävande och lite stakande: "[...] det gjorde...nja, det gjorde dom säkert, men jag tänkte...då var det ju inte...då när tyskarna närmade sig och var redan med flyget och allt sånt där”. När Anna berättar om kriget handlar det främst om att hon tyckte att det var obehagligt med mörk-

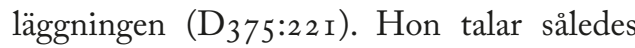
inte specifikt om rädsla från ett svenskjudiskt perspektiv utan snarare utifrån positionen som en ung mörkrädd flicka. Anna berättar att föräldrarna läste om maktövertagandet i tidningen, men hon säger att hon inte har några minnen av att någon av de vuxna talade med henne om nazismen eller vad som hände med judarna i Europa.

Intervjun med Barbro inleds med att hon ombeds att börja sin berättelse i staden där hon är född, vilket hon också gör. Barbro berättar om sin barndom, skolgång och familjens flytt 
till Stockholm. Intervjuaren Ingrid Lomfors skyndar på berättelsen genom att be Barbro att hoppa fram till I 930-talet. Barbro svarar: "Då tog jag studenten”. Intervjuaren ber inte henne att berätta om hur det var att ta studenten utan frågar i stället om hon har något minne av Hitler och makttillträdet. Under den här intervjun är det således främst intervjuaren som söker att skapa en levnadsberättelse som förhåller sig till andra världskriget och Förintelsen, snarare än till personliga milstolpar som exempelvis studenten. ${ }^{6}$ Barbro svarar på intervjuarens fråga om hon har några minnen av Hitler och makttillträdet:

\begin{abstract}
Nja, det har jag väl men vi tog det väl inte särskilt allvarligt. Men jag minns att min mamma talade med någon väninna i telefon som sa att...hon var från Tyskland från början men hade bott i många, många år $\mathrm{i}$ Sverige - hon sa att hon inte hade kunnat sova på hela natten när Hitler hade tillträtt. Och vi ungdomar i familjen som lyssnade till samtalet vi tyckte det var ganska larvigt för det där det var väl någonting övergående. Så vi tog det inte...länge, tror jag, trodde vi att det inte skulle bli något särskilt allvarligt. Det var en galenpanna som många andra. (D375:2 I 7$)$
\end{abstract}

I likhet med Anna berättar således Barbro om sin reaktion på det nazistiska maktövertagandet från ett barns perspektiv. Deras berättelser handlar om hur de som barn eller unga kvinnor reagerade främst på de vuxnas reaktioner på det nazistiska maktövertagandet och händelseutvecklingen i Europa. När Carl, som växte upp i Lund, tillfrågas om

6 Se Thor Tureby 2o r ga för en diskussion om hur de insamlade berättelserna kan förstås som en hybrid mellan en levnadsberättelse och ett vittnesmål om andra världskriget och Förintelsen. hans föräldrar pratade om Hitler, nazismen och kriget svarar han att de talade mycket lite om det i hemmet. Intervjuaren Britta Johansson frågar honom varför han tror att det var så och Carl svarar kortfattat: "Det var väl svårt." Sedan tillägger han att föräldrarna evakuerade familjen till några bönder som fadern kände i samband med att Norge och Danmark ockuperades i april r 940: "Men vi var där bara tror jag en vecka, sen så flyttade vi hem igen.” Intervjuaren Britta Johansson följer inte upp detta uttalande utan intervjun byter spår och börjar i stället att handla om Carls utbildning (D375:259). Det är synd att Carl inte får fler frågor om evakueringen. Föräldrarnas agerande indikerar att de hade förstått, redan I940, att det var bäst för en judisk familj att gå under jorden om Sverige ockuperades. Forskning om hur den judiska minoriteten i Sverige reagerade på nazisternas maktövertagande har främst fokuserat på hur och vad de gjorde för att hjälpa Europas förföljda judar. Därmed har de särskilts från gruppen förföljda judar. Men även de svenska judarna levde ju under ett potentiellt hot. De svenska judarnas rädslor och strategier för att hantera den alltmer hotfulla händelseutvecklingen i Europa har dock sällan beaktats eller undersökts av tidigare forskning. ${ }^{7}$ Vad visste de? Hur tänkte de? Vad sa man till barnen? Vilka strategier, som exempelvis den ovannämnda evakueringen, existerade för att hantera det annalkande hotet om en nazistisk ockupation? En ockupation och händelseutveckling som våren 1940 måste ha tett sig som högst sannolik. Möjligen ska Carls berättelse även förstås ur ett lokalt skånskt

7 Temat har dock berörts av journalisten Bernt Hermele i boken Kommer de, så skjuter jag oss. Om svenska judars liv $i$ skuggan av forintelsen (Stockholm: Lind \& Co, 20 I 8). Hermeles framställning bygger delvis på det insamlade materialet i "Judiska minnen". 
perspektiv. Det är även sannolikt att ockupationen av grannländerna upplevdes som ett mer konkret hot för personer som var bosatta i närheten av den norska eller danska gränsen än för personer som bodde i Stockholm eller längre norrut. När jag inom ramen för min avhandling om Hechaluz 8 i Sverige intervjuade chaluzim som befann sig på den skånska landsbygden under i 940-talet berättade en man att de fick instruktioner från ledningen att"hålla sina cyklar i beredskap". Om nazisterna landsteg i Skåne var instruktionen till Hechaluz medlemmar att de skulle cykla norrut (Thor 2005: 287). Hotet om en nazistisk ockupation torde ha präglat vardagen för alla av judisk börd - infödda, inflyttade eller flyktingar - som befann sig i Sverige under I940-talets första år. Detta är ett exempel på historisk kunskap som kan nås genom att använda oral history eller andra egodokument, nämligen kunskap om rädslor och andra känslor som sannolikt även påverkade hur personer agerade eller inte agerade i olika situationer. En aspekt som förmodligen inte framkommer vid arbete med och analyser av statliga dokument eller församlingens arkiverade handlingar, vilken tidigare forskning främst använt sig av (jfr Stone 2018).

David tillfrågas inte direkt om han har något minne från nazisternas makttillträde eller vad det pratades om i hemmet i relation till Hitler och nazismen, utan han får i stället

8 Hechaluz (hebreiska: pionjären) var en sionistisk ungdomsrörelse som etablerades i Ryssland och Europa under början av I 900-talet. Rörelsens mål var att förbereda sina medlemmar (chaluzim, hebreiska: pionjärerna) för att flytta och bosätta sig i Palestina för att bygga det nya judiska hemlandet. Under I930-talet blev den tyska Hechaluz-rörelsen en paraplyorganisation för flera pionjära sionistiska ungdomsrörelser och skapade också utlandsavdelningar, bland annat i Sverige. Se Thor 2005 . frågan om hur gammal han var när nazisterna fick makten. Han berättar att han var tio år när nazisterna fick makten och sexton år när kriget startade. David säger att han främst minns lättnaden han kände vid krigsutbrottet. En lättnad som han tror att han upplevde på grund av att äldre personer förmedlade att de kände så. David menar nämligen att han själv var för ung för att riktigt förstå vad som pågick, men att han hade en föreställning om att Storbritannien och Frankrike nu skulle ställa allt till rätta och att "nazismen skulle upphöra". David får frågan om han tror att han var mer påverkad av det som hände $\mathrm{i}$ världen än andra, eftersom han var jude. Han svarar:
Ja. Jag var nog påverkad väldigt tidigt där- för det fanns så mycket judiska flyktingar som umgicks i vårt hem och vi hade även en judisk flyktingflicka boende hos oss, så man hade hela tiden någon sorts kontakt med, på det sättet också, med den verklig- heten. $\left(\mathrm{D}_{375: 232)}\right.$

I Davids svar på frågan om han tror att han påverkades mer än andra (underförstått icke-judiska svenskar) eftersom han var jude, påtalar han inte någon egen rädsla för vad som skulle kunna hända honom eller hans familj. Han berättar i stället om judiska flyktingar och en judisk flyktingflicka som bodde hos hans familj. David relaterar till dessa personer med uttrycket "den verkligheten". Han berättar således om det nazistiska maktövertagandet och händelseutvecklingen som något som hände de andra, de andra "judarna", "de judiska flyktingarna", och inte honom eller de svenska judarna.

Generellt går det utifrån de fyra intervjuades berättelser, som sinsemellan är mycket olika, ändå att fastslå att det främst är barns eller ungdomars perspektiv som framträder i berättelserna. Detta gäller för det 
"svenskjudiska" materialet som helhet i samlingen "Judiska minnen". Majoriteten av dem som har intervjuats eller som har sänt in sina skriftliga levnadsberättelser var barn eller tonåringar när nazisterna fick makten i Tyskland. De beskriver således främst hur föräldrarna reagerade på det nazistiska maktövertagandet och händelseutvecklingen i Europa och inte sina egna upplevelser. Hur föräldragenerationen kan ha upplevt situationen belyses av en av de få inskickade levnadsberättelserna som är författad av någon som tillhörde den äldre generationen:

Då, I 939, kände vi en isande fruktan, och med allt skäl - vart skulle vi ta vägen, om det värsta hände? Med våra fem barn? Ibland på gatan, i butikerna, när folk hälsade vänligt på mig som de brukade, hände det att jag tänkte: ”Ja, du, nu hälsar du vänligt - hur blir det om Hitler kommer, vänder du bort huvudet då?” Denna misstänksamhet kändes förnedrande, och i tankarna bad jag vederbörande om ursäkt efteråt. $\left(D_{375:{ }_{3}}\right)^{9}$

Berättelsen är tämligen ovanlig i sitt slag, det vill säga en vuxen persons, en moders perspektiv på hur hon skulle kunna skydda sin familj, fly med sina barn om nazisterna kom, i den svenskjudiska samlingen. Utöver ovan citerade berättelse finns en levnadsberättelse författad av en kvinna som var 25 år gammal när hon gifte sig med en man som kommit till Sverige som flykting i 937. Även hon redogör för att hon funderade över varthän de skulle fly om nazisterna kom. Kvinnan uttrycker också att i och med äktenskapet med en flykting uppdagades allvaret och

9 Denna skriftliga levnadsberättelse skiljer sig från andra insända levnadsberättelserna eftersom den är en avskrift från en minnesbok författad 1974 . faran med att tillhöra det judiska folket för henne. Något som hon tidigare inte reflekterat över som svensk judinna. Hon menar att hennes "trygga barndom" och "de sköna, sorglösa ungdomsåren försvann" när hon valde att gifta sig med en flykting (D375:66). En annan kvinna berättar om att hon och hennes make bytte efternamn efter nazisternas maktövertagande. Maken var affärsman och kvinnan menar att ingen ville eller vågade handla med någon med ett judiskt klingande namn efter maktövertagandet i Tyskland. Annars menar kvinnan att förutom att det var"obehagligt", så var det bra i Sverige. Hon märkte inte av nazisternas maktövertagande

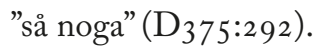

Majoriteten av de insamlade levnadsberättelserna är som tidigare nämnts från personer som var barn eller ungdomar under Förintelsen. De ger uttryck för att de inte riktigt förstod vad som hände i Europa eller att deras föräldrar höll dem lyckligt ovetande:
Min barndom var trots allt som hände ute i världen mycket trygg och lycklig, en sak som förvånat mig mycket. Hur lyckades mina föräldrar hålla oss barn utanför all ångest och oro? $\left(D_{375}: 69\right)^{10}$

Vid insamlingen av material från dem som kategoriserades som "svenskfödda judar" gjordes inte någon åtskillnad mellan personer som tillhörde de judiska släkter som funnits i Sverige sedan I 70o-talet eller de som invandrade under sent I 800-tal eller tidigt I 900-tal. Huruvida berättarnas föräldrar var del av den förstnämnda eller sistnämnda gruppen påverkade naturligtvis också erfarenheterna av och minnena från krigsåren. De nyligen anlända till Sverige hade i flera fall släktingar och vänner kvar i Europa som de stod

10 Se även $\mathrm{D}_{375: 42}$ för en liknande berättelse. 
i ständig kontakt med. De var därför även sannolikt mer välinformerade om händelseutvecklingen än de familjer som sedan länge funnits i Sverige och som därmed knappt hade några band till andra länder. En kvinna, som föddes i Sverige I 920 och som alltså var I 3 år I 933 när nazisterna fick makten och vars pappa hade invandrat från östra Europa några år innan hon föddes, svarar på frågan om hon hörde talas någonting om vad som pågick i Europa:

Ja, o ja, för pappa var ju väldigt aktiv med att...det sas ju då att folk var tvungna att fly och så vidare. Och väldigt många utav hans syskon omkom så småningom $\mathrm{i}$ koncentrationsläger. Han gjorde mycket, mycket allvarliga försök att få hit så mycket folk utav sina släktingar som möjligt. Han var flera gånger uppe och pratade med Utrikesdepartement om att få inresetillstånd för dom, och han var otroligt aktiv. Han [...] talade dålig svenska [...] men det hindrade honom inte ifrån att $[\ldots]$ va[ra] väldigt aktiv för att få hit släktingar [...]. (D $375: 2$ I 7 )

Citaten ovan synliggör att de som kategoriserats som svenskfödda judar i samlingen inte är någon homogen grupp. De som tillhörde familjer som invandrat till Sverige under sent I 800-tal eller tidigt I 900-tal tenderar att ha haft en mer välinformerad insikt i vad som pågick i Europa och händelseutvecklingen präglade även deras vardag, eftersom de själva eller deras föräldrar sökte att hjälpa kvarvarande släktingar att komma till Sverige (se även $\mathrm{D}_{375: 18,} \mathrm{D}_{375: 49 \text {, }}$ $\mathrm{D}_{375: 89}, \mathrm{D}_{375: 290) \text {. }}$

Pappa skickade också paket och pengar till sin familj i Lettland. När tyskarna kom dit, tog de pengarna, men paketen kom tillbaka med texten "adressaten okänd". Pappa hörde aldrig mera av sina närstående, de två kvarvarande systrarna, i Lettland. (D $375: 49)$

För vissa svenskjudiska familjer handlade det således inte om att hjälpa "Europas förföljda judar", utan om att hjälpa familjemedlemmar, släktingar och vänner. De var följaktligen allt annat än passiva, även om det kanske inte alltid handlade om kollektivt organiserade hjälpaktioner av någon församling, utan snarare om privata initiativ. Denna typ av hjälpverksamhet går inte till fullo att undersöka utifrån statliga eller de judiska församlingarnas arkiv, eftersom dylika verksamheter sällan lämnat något spår i dessa arkiv. Berättelser om de individuella initiativen och hjälpen till släktingar är således ytterligare ett exempel på ny kunskap om det judiska hjälparbetets mångfacetterade karaktär som vi kan nå genom att arbeta med oral history och berättelser som källmaterial.

\section{Berättelser om flyktingar}

I utdraget ur Davids berättelse ovan, berättade han om det nazistiska maktövertagandet och händelseutvecklingen som något som hände några andra, i en annan verklighet. I samband med detta nämner han att familjen hade en inneboende flyktingflicka. Uppgifter om "flyktingflickor" eller "flyktinggäster" förekommer i flera av de andra insamlade levnadsberättelserna. Det synliggör måhända hur vanligt det var och, återigen, en uppdelning av den privata och den offentliga sfärens hjälpverksamhet. I det privata förändrades dessutom gränserna för vem som betraktas som flykting och familj tämligen snabbt, men även över tid. I några berättelser finns en sådan ambivalent hållning till den så kallade "flyktingflickan" i familjen: å ena sidan beskrivs hon som någon som var anställd som barnflicka eller som hushållerska, å andra 
sidan påstås hon, utan att nämnas vid namn utan som "flyktingflickan", samtidigt "vara som ett barn i huset". ${ }^{11}$

I intervjun med Carl förekommer generellt få berättelser om flyktingar. De skildringar som finns är relaterade till berättelser om den egna familjen. Carls familj tog I 944 emot en judisk pojke från Finland som bodde hos familjen i nio månader fram tills krigsslutet. ${ }^{12}$ Carl berättar om att han fäste sig mycket vid pojken och lovade att komma och hälsa på honom så snart han kunde när pojken reste tillbaka till Finland, vilket han även gjorde i slutet av I945. Då träffade han även pojkens syster för första gången - en ung kvinna som senare blev hans fru. Poängen i Carls berättelse om flyktingar, om familjens "finska flyktingpojke" är främst att pojkens syster senare blev hans hustru. Det är inte primärt en berättelse om att Carls familj var engagerad i mottagandet av judiska flyktingar. Berättelsen ger även ett tydligt exempel på hur flytande gränsen mellan "dem" (flyktingarna)

11 Se t.ex. $\mathrm{D}_{375: 14}, \mathrm{D}_{375}$ : $18, \mathrm{D}_{375: 49 \text {, }}$

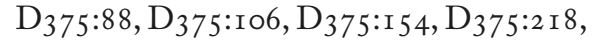

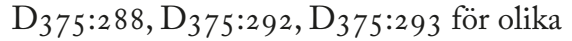
berättelser om flyktingbarn, flyktingflickor eller flyktinggäster. I flera av berättelserna nämns att föräldrarna tar emot ett barn från Tyskland eller Österrike, senare även en eller flera flyktingar från Danmark eller Finland och ibland även någon från gruppen som benämns "överlevande" I 945 .

12 Våren I 944 tog församlingen i Stockholm emot 54 judiska barn från Helsingfors, I4 barn från Åbo och 6 barn från Viborg. Församlingen lovade i juli I 944 att ta emot ytterligare 300 finländska judar (åldringar och sjuka) samt 20 judiska kvinnor med barn, men denna operation förverkligades inte. Se Torvinen I 989: I 5 6-I 57 . Även om det var församlingen i Stockholm som tog emot de judiska barnen indikerar Carls berättelse att aktionen genomfördes i samarbete med de andra judiska församlingarna i Sverige, emedan Carls föräldrahem låg i Lund. och "oss" (mottagarna) är och att gränsen och uppdelningen förändras över tid. Det som då var "familjens finska flyktingpojke" är i nutid en svåger. Carls berättelse belyser även språkets betydelse för interaktionen mellan "hjälpare" och "hjälpta". Den finsk-judiske pojken som bodde hos Carls familj hade förmodligen svenska som modersmål, vilket sannolikt bidrog till att han fann sig tillrätta trots de svåra omständigheterna. Det gemensamma svenska språket innebar även att kontakten lätt kunde vidmakthållas efter att pojken hade återvänt till Finland. Jag återkommer till språkets betydelse för erfarenheterna och utformningen av hjälpverksamheten längre fram i texten.

Såväl Carl som David berättar således knappt någonting om möten med eller eget hjälparbete för flyktingarna. När dessa teman berörs under intervjun handlar berättelserna snarare om att männens familjer tog hand om ett barn under en kortare eller längre tid. Det är synd att intervjuarna inte ber de båda männen att vidareutveckla berättelserna om hur det gick till när deras familjer tog emot den s.k."flyktingflickan" eller "flyktingpojken" i sina hem. Vad tänkte de själva på som barn i relation till dessa pojkar och flickor? Hur påverkades deras syn på den egna identiteten och familjen? Hur betraktade de pojkarna och flickorna som kom? I Davids berättelse synliggörs en distinktion mellan de svenska judarnas och flyktingarnas verklighet, där "familjens flyktingflicka" får representera den andra verkligheten. "Familjens flyktingflicka" nämns aldrig vid namn. Intervjuaren frågar inte heller efter hennes namn. Hon frågar inte heller hur David såg på denna flicka, hur länge hon stannade i Davids familj eller vad som hände med flickan när kriget var slut.

När Anna får frågan om när flyktingarna började komma till Sverige tror hon först att intervjuaren Britta Johansson menar de befriade koncentrationslägerfångarna och hon 
börjar att tala om sina möten med personer från denna grupp. Intervjuaren undrar då om det inte kom några flyktingar tidigare. Anna svarar först nej, men drar sig sedan till minnes att det ju visst kom flyktingar, till olika bondgårdar där de arbetade som drängar, i närheten av Kristianstad, där hon växte upp. Britta bemöter detta uttalande med "men det var inte några som du umgicks med?" Hon förutsätter alltså att Anna inte umgicks med dem. Vilket indikerar att hon utgår ifrån r 990-talets samtida diskurs som gjorde gällande att de svenska judarna ignorerade de judiska flyktingarna i Sverige. Anna svarar dock "jodå" och berättar om hur flyktingarna,"pojkarna", kom och hälsade på i hennes barndomshem och i synagogan, men även att de inviterade folk till sin drängstuga och bjöd på kaffe, smörgåsar och kakor. Anna tillägger dock att det främst var hennes äldre syskon som umgicks med dem, eftersom hon var yngre än de. Det finns en självklarhet i Annas berättande om att hon och hennes syskon naturligtvis umgicks med dessa pojkar - eventuellt därför att de var judiska, men kanske framförallt på grund av pojkarna

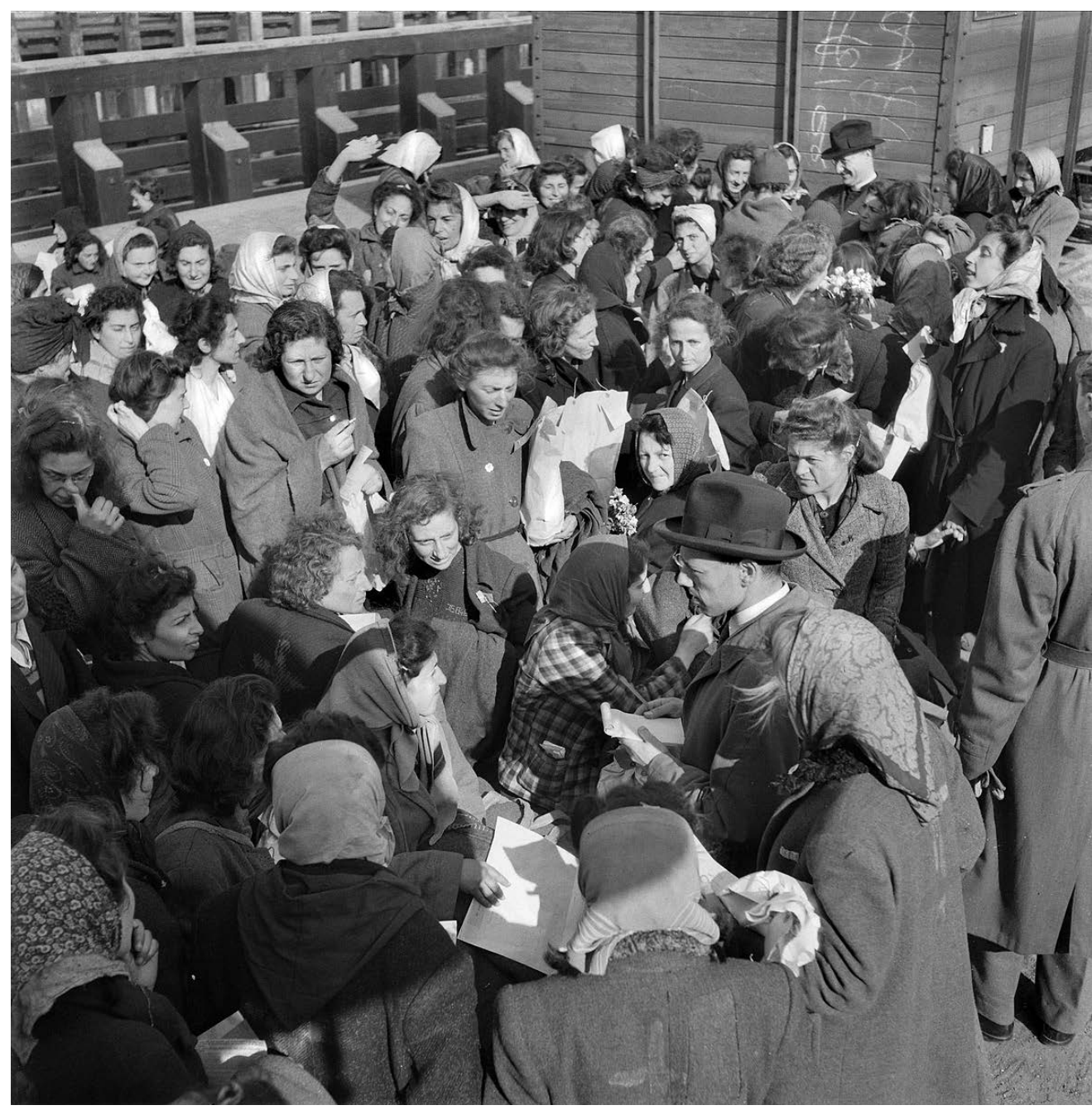

Flyktingar. Folk Bernadottes expedition med de Vita bussarna. Ankomst till Sverige via Helsingborg och Malmö. K. W. Gullers. Nordiska museet (CC BY-NC-ND). 
liksom de själva var ungdomar. Britta frågar senare under intervjun om de berättade något om vad som hade hänt dem innan de kom till Sverige. Anna berättar då bland annat att en pojke hade berättat för henne om hur hans pappa tvingats se på när hans mamma sköts. Pojkarna hade fått lämna allt och upplevt många ruskiga saker, sammanfattar hon (D)75:221).

Annas berättelser om de flyktingar som hon mötte under krigsåren berättas återigen främst från ett barns eller en ung kvinnas perspektiv. Hon identifierar sig framförallt med dem utifrån positionen som ett barn/en ung kvinna och pratar om hur svårt det måste ha varit för dem, för pojkarna, att lämna allt, att lämna sina föräldrar och att komma till Sverige och tvingas att försörja sig som drängar. Samtidigt framhåller Anna att hon uppskattade deras ankomst och närvaro i hennes hemstad. Pojkarna beskrivs genomgående av Anna som sociala och trevliga att umgås med. Hon menar att de utgjorde ett välkommet tillskott till det ringa judiska umgänget i Kristianstad. Det är också uppenbart att Anna, både som barn men även som vuxen i ett retrospektivt perspektiv, främst betraktar det som hände judarna i Europa, förföljelsen och Förintelsen, som något som drabbade dem - inte henne, hennes familj eller någon annan som tillhörde den judiska minoriteten i Sverige.

Under intervjun med Barbro förkommer flera berättelser om flyktingarna under I930- och r940-talen. På intervjuarens, Ingrid Lomfors, påstående: men sedan började det komma flyktingar till Sverige och de kom till ert hem också, svarar hon: "Jadå, vi hade redan tidigt folk som åt hos oss." Sedan följer en utläggning om att det på den tiden inte fanns någon statlig flyktinghjälp utan att församlingen fick ta hand om flyktingarna. Barbro berättar vidare att alla flyktingar inte fick arbetstillstånd varför de försörjdes av församlingens medlemmar. Alla svenska judar var tvungna att tillhöra en församling som de betalde skatt till, berättar Barbro. Hon nämner även att det gjordes olika insamlingar och att åtskilliga familjer tog hand om en eller flera flyktingar, på så sätt att de fick komma och äta ett mål mat om dagen tillsammans med familjen. Flera av dem som har intervjuats berättar, som tidigare nämnts, om middagsgäster eller "flyktingpojkar" eller "flyktingflickor" som bodde i hemmet under längre eller kortare perioder. Barbro berättar:

\section{Vi hade två barn här i Sverige, här i Stock- holm, i vår familj, en pojke och en flicka. Egentligen skulle vi bara haft en flicka som var I 5 år, I 4-I 5 år, men så kom farmor och frågade om vi inte kunde ta pojken också, så vi tog pojken. $\left(\mathrm{D}_{375: 224}\right)$}

\section{Intervjuaren frågar då, "Vems farmor?"} Och Barbro svarar: "Flickans farmor". Intervjuaren undrar då varför inte farmodern kunde ta hand om barnen. Barbro förklarar att farmodern var "en fattig immigrant". Hon berättar vidare att många flyktingfamiljer i Sverige ville vara med och hjälpa genom att till exempel ta emot ett barn som kom med Kindertransport I938. Flyktingfamiljerna hade dock ofta inte råd att ta emot ett barn, men det kunde ändå ordnas, berättar Barbro. Hennes bröder, som var ogifta, betalade till exempel en judisk flyktingfamilj för att den tog emot en pojke. Flyktingfamiljen hade inte råd, men ville hjälpa. "Så det löstes på

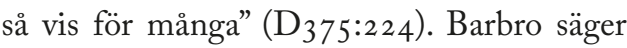
aldrig rakt ut att hennes bröder inte kunde ta emot några barn i sina hem, eftersom de var ensamstående och män. Den informationen lämnas ändå genom upplysningen om att de var ogifta. Vem som kunde hjälpa, och hur olika personer kunde hjälpa, handlade således om pengar, men även om kön och familjesituation $\left(\mathrm{D}_{375: 224}\right.$, se även $\mathrm{D}_{375: \mathrm{I}} 8$ och 
D 375:106). Barbros berättelse om den judiska flyktingfamiljen som tog emot en pojke som försörjdes av hennes bröder belyser även att "flyktingar" kunde vara aktiva "hjälpare" och delaktiga i flyktinghjälpen och att uppdelningen mellan "hjälpare"/svenska judar och "hjälpta"/flyktingar inte alltid gällde.

I dialogen mellan Barbro och Ingrid Lomfors framkommer även vid flera tillfällen att det främst var kvinnor som oavlönat utförde mycket av insamlingsarbetet och det praktiska omhändertagandet av flyktingarna. Barbro berättar till exempel att hon själv arbetade heltid och oavlönat med hjälparbetet. På Ingrids fråga "Var du avlönad?" svarar Barbro: ”Nej, det var frivilligt. Det gick på pappas lön och fickpengarna rättare sagt” (D 375:224). Hjälparbetet var således könat, men även klassat. Det var enbart kvinnor som försörjdes av sin familj som kunde engagera sig i ett oavlönat hjälparbete som organiserades kollektivt av församlingar eller olika hjälpkommittéer. Historikern Izabela A. Dahl har framhållit att kvinnors engagemang i flyktinghjälpen är en aspekt som ofta konstateras, i den begränsade forskning som föreligger om flyktinghjälpens organisation, men att denna aspekt av flyktinghjälpen fortfarande är mer eller mindre outforskad (Dahl 20I8). Jag menar att en anledning till den begränsade forskningen om kvinnorna (men även flyktingarna) som centrala aktörer i olika hjälpverksamheter delvis skulle kunna förklaras utifrån att vissa typer av verksamheter lämnar dokument i form av exempelvis protokoll efter sig. Annan typ av verksamhet såsom omsorg, vårdande och praktiskt arbete lämnar inte samma pappersspår efter sig och är därför svårare att finna och belägga i arkiven, vilket kan vara en möjlig förklaring till varför det har saknats forskning om kvinnornas engagemang i flyktinghjälpen. Det handlar om vilka källor som har funnits tillgängliga för historiker, men även vilka arkiv, källor och perspektiv som historiker valt att arbeta med (jfr Thor Tureby 2or gb). Här anknyter jag även till Peter Gatrell som argumenterar för att historiska perspektiv, men även olika källmaterial och inte enbart dokument som arkiverats av regeringar eller hjälporganisationer och därmed förmedlar deras definitioner och perspektiv, behövs inom refugee studies för att synliggöra vems och vilka erfarenheter, handlingar och röster som ansågs och anses viktiga att förmedla såväl i det förflutna som i samtiden (Gatrell 2013:283-296).

Berättelserna om det oavlönade hjälparbetet väcker även frågor om hur eventuella klasskillnader påverkade interaktionen mellan de svenska judarna och flyktingarna. Om detta avslöjar dock det insamlade materialet i samlingen "Judiska minnen" väldigt lite, eftersom få frågor ställdes under intervjuerna om klass eller ekonomiska förutsättningar, vilket indikerar att detta inte var frågor som intresserade dem som initierade samlingen och genomförde intervjuerna. I några berättelser omnämns dock familjens flyktingflicka omväxlande som en "gäst" men även som en "barnflicka" eller "hushållerska", vilket antyder en hierarkisk situation där flyktingflickan inte inkluderades villkorslöst i familjen utan fick arbeta och göra rätt för sig. Flera av de personer som kom till Sverige framförallt under I 930-talet tillhörde själva medel- eller övre medelklassen i Tyskland eller Österrike innan flykten. Flykten innebar för många ett steg nedåt på klasstegen. Hur detta upplevdes kan dock inte det material som föreliggande text bygger på svara på, utan då måste vi även lyssna till de insamlade berättelserna från de som är kategoriserade som flyktingar eller överlevande i samlingen.

Ingrid Lomfors undrar under intervjun med Barbro: "[...] flyktingarna kring bordet, pratade man om vad de hade varit med om eller undvek man det?” Barbro svarar att hon tror att man undvek det. Hon tillägger 
även att hon inte tror att de första flyktingarna hade varit med om så förfärligt mycket. Man begrep inte vad det var frågan om förrän efter Kristallnatten, menar Barbro. Hon framhåller i samband med detta uttalande också att"församlingen försökte ju på alla sätt att ta hand om dom och gjorde olika insatser [som] man [inte] ska [...] glömma bort" $\left(\mathrm{D}_{375: 224}\right)$. Hon berättar sedan om hur församlingen ordnade inresevisum för 500 judiska barn efter Kristallnatten och på vilket sätt hon var engagerad i det arbetet. Barbro berättar således om flyktingarna främst från församlingens och en hjälparbetares perspektiv. Hon talar ofta utifrån en försvarsposition och det är tydligt att hon är medveten om att de svenska judarna har kritiserats för sin förmenta bristande vilja att hjälpa Europas förföljda judar. Barbro är väl medveten om kritiken och bemöter den ständigt under intervjun, även när den inte uttalas av intervjuaren Ingrid Lomfors. En bit in i intervjun lyfter dock intervjuaren fram en del av denna kritik explicit, när hon yttrar följande:

Du vet nu på senare år så har man ju diskuterat det svensk-judiska ledarskapets agerande under dom här åren, minns du om det fanns [...] nån generationsskillnad i synen på hur dom judiska ledarna agerade för flyktingar till exempel? $\left(\mathrm{D}_{375: 224}\right)^{13}$

Barbro svarar då att hon inte tror att det fanns någon generationsskillnad. Hon

13 Se även $\mathrm{D}_{375: 2 \text { I } 8}$ där intervjuaren Ingrid Lomfors formulerar en liknande fråga om den yngre generationens kritik av den äldre till en person i Malmö, där den judiska ungdomsföreningen ska ha kritiserat ordföranden och de äldre medlemmarna i församlingen för att de inte tog bättre hand om de flyktingbarn från Tyskland som vistades inom församlingens upptagningsområde. framhåller även, att hon själv hyser mycket stor respekt för Gunnar Josephson, som var församlingens ordförande. Barbro menar också att det är väldigt lätt att komma i efterhand och säga: "Man skulle ha gjort si eller så." Ingen kunde ju tro, menar hon, att det som hände skulle hända. Vidare betonar hon att det var omöjligt att genomdriva hos de svenska myndigheterna att "vi" (den judiska minoriteten) skulle få ta emot så många flyktingar som vi ville. Barbro ignorerar således Ingrid Lomfors påstående om att det möjligen fanns en skillnad mellan hur olika generationer upplevde församlingens agerande. Istället talar hon återigen utifrån en försvarsposition och försvarar först kollektivet "vi" som här sannolikt är liktydigt med församlingen i Stockholm eller möjligen den judiska minoriteten i Sverige - för att senare gå ner på individnivå för att bemöta kritiken (som aldrig yttras av intervjuaren, men som Barbro likväl bemöter) gentemot församlingens ordförande Gunnar Josephson.

Hon berättar även om att det fanns "fanatiker eller personer som var besatta av en god vilja och kanske inte alltid kunde bedöma vilka situationer man [den judiska minoriteten/församlingen] hade emot sig och hur stora svårigheterna var”. Barbro återkommer till att varken hon eller någon annan visste vad som skulle ske [att förföljelsen skulle utvecklas till Förintelsen] och att det inte gick att övertyga de svenska myndigheterna om att ta emot fler flyktingar. Efter detta uttalande återkommer Ingrid Lomfors till frågan om olika generationers perspektiv:

Men var det så att du träffade på människor, dina föräldrars generation, som var väldigt passiva, så när du träffade dom kände att kan ni inte göra mer? Och så där lite upproriskt, ungdomsaktigt?

(D $375: 224)$ 
Barbro svarar att hon inte kan komma ihåg att det var någon som egentligen sa:"Kan vi inte göra mer?” Hon påpekar återigen att församlingen hade ett "kolossalt ansvar", ett ekonomiskt ansvar. Barbro positionerar sig aldrig som ungdom när församlingens agerande diskuteras under intervjun, utan talar från positionen som någon som företräder församlingen. Trots intervjuarens påstående att Barbro i egenskap av ungdom och tillhörande den yngre generationen således borde ha kritiserat sina föräldrars generation, som enligt intervjuaren var passiv, intar hon inte positionen som upprorisk ungdom som intervjuaren föreslår och erbjuder henne.

Det är således tydligt att såväl den intervjuade som den som intervjuar förhåller sig till den samtida kritiken av den mosaiska församlingens flyktingpolitik och flyktingarbete. När intervjun med Barbro jämförs med andra intervjuer så synliggörs även att hon talar från en mycket insatt position, som företrädare för församlingen i Stockholm. Det är tydligt att hon har kunskap om vad som gjordes från församlingens sida, men även vilka begränsningar som fanns i hur och vad som kunde göras. Hon säger därför att hon inte kan dra sig till minnes om det fanns några personer som tyckte man skulle göra mer, eftersom församlingen och dess ledningen, enligt hennes förmenande, gjorde allt som stod i deras makt att göra. Att det fanns andra som tyckte att man skulle göra mer, och försökte göra mer, är dock framträdande i andra berättelser där berättaren har en pappa eller mamma som inte var svenskfödd. Där återges i stället föräldrarnas eller den egna kampen för att försöka skaffa inresevisum till släktingar som fortfarande befann sig i Europa:

Inte heller bland judarna som ledde mosaiska församlingen var det lätt att få gehör - jag sökte att få hit min moster från Riga som tidigare tagit hand om mig - men ledningen här i staden var ovillig att hjälpa till...alltför många judiska invandrare kunde bara skapa mer antisemitism, och det kunde bli svårare för de judar som redan bodde här. $\left(\mathrm{D}_{375}\right.$ : 18$)$

Berättelsen om kampen för släktingarna är inte alltid kontextualiserad som en kritik av församlingen som ovan, men synliggör och utgör ett exempel på att de svenska judarna var en heterogen grupp med skilda kunskaper, möjligheter och erfarenheter av vilken hjälpverksamhet som gick att organisera och genomdriva i församlingens regi (se även D375:217).

\section{Berättelser om möten med de överlevande}

När Anna tog kontakt med den pågående insamlingen vid Nordiska museet var det för att hon ville berätta om sina möten med de överlevande under våren och sommaren I 945. Under intervjun berättar hon om hur hon en vårdag var ute och gick. Hon tittade upp mot skolan där hon själv har gått som elev och såg att det hängde människor ut från varje fönster i skolan. Anna berättar att hon gick fram till skolan och tittade in genom ett fönster och såg en massa sängar och massor av män: "Ja, alltså bara att se dom, det var en sån chock. Jag trodde inte att jag såg rätt. Dom såg ut [som] någonting, så bedrövligt hemskt" (D375:22I). Anna berättar sedan en lång historia om hur hon gick hem till sin pappa och bad om pengar för att köpa bröd och korv till männen. Hon berättar även om den förtvivlan hon kände när hon insåg att hon enbart hade gett mat till männen på första våningen. Anna berättar vidare, att det var en chockartad upplevelse första gången hon såg de överlevande, men att de så småningom slapp att sitta i karantän och att flera av dem då började umgås med henne och hennes familj. Hon säger att de överlevande 
inte hade några egna kläder, varför hon och hennes syster lånade ut sina kläder och skor till dem. Anna och hennes syster gav dem även läppstift och sjaletter (eftersom de inte ville visa att de inte hade något hår) och gick ut på stan tillsammans med dem: "Dom gick med en hållning precis [...] som en mannekäng: Här kommer jag. Så malliga och glada var dom" (D $375: 22 \mathrm{I}) .{ }^{14}$

Även Barbro har mycket att berätta om de överlevande, men från ett annat perspektiv. Hon arbetade med mottagningen i Malmö när de överlevande kom våren och sommaren 1945. Barbro berättar att hon och de andra judiska hjälparbetarna stod på stranden och sa shalom när de trodde att de som kom iland var judar. Ingrid Lomfors frågar Barbro om det inte var "fruktansvärt hemskt att se detta". Jo, det var oerhört fruktansvärt svarar Barbro och berättar att de överlevande såg hemska ut och luktade mycket illa. Hon berättar framförallt ur ett organisatoriskt perspektiv, om hur och vad man gjorde för de överlevande, att hon lät trycka upp registreringsformulär och hur verksamheten organiserades. Hon säger att det var väldigt mycket att göra:

Det var ju sammanlagt tror jag I 2000 som kom och som då dels skulle resa vidare och sökte kontakter och behövde hjälp och så vidare. Dom klagar nu bittert, dom som är kvar, att dom fick så lite besök och så lite hjälp, men jag brukar alltid säga till dom att det var dubbelt så många judar som kom som fanns i Sverige. Det var inte lätt. $\left(\mathrm{D}_{375: 224)}\right.$

14 Intervjun med Anna innehåller fler berättelser om umgänget med de överlevande än vad det finns utrymme för att redogöra för här.
Återigen intar Barbro en försvarsposition i sitt berättande. Det är uppenbart att hon strukturerar sitt berättande i relation till den kritik som har riktats mot den svenska judenhetens agerande i relation till flyktingar och överlevande. Barbro talar ofta i förstapersonpluralis (vi och oss) och främst som en representant för den judiska gemenskapen eller församlingen i Stockholm. Hennes levnadsberättelse innehåller inte några berättelser om personliga eller privata möten, vänskaper eller samvaro med flyktingar eller överlevande.

Carl berättar inte heller om några personliga möten med de överlevande, trots att han flyttade från Lund och till Stockholm för att arbeta på församlingens kontor vid krigsslutet. Intervjuaren, Britta Johansson, försöker få honom att berätta om arbetet, om vilka arbetsuppgifter han hade eller vad han hörde om hjälparbetet och de befriade. Carl svarar mycket kortfattat på intervjuarens frågor och nämner främst namn på andra personer som arbetade inom församlingen med flyktingarna och de överlevande. På frågan om det förekom klagomål mot församlingen svarar Carl kortfattat att han inte tror det

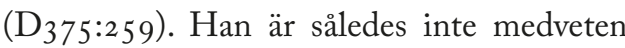
om kritiken mot församlingen eller så väljer han att inte bemöta den.

På frågan om han har några vänner som är överlevande läser Carl ett avsnitt ur en bok som är skriven av Hédi Fried (1998) där hon skriver om hur hon och hennes syster träffar en far och en son som bjuder hem dem för att fira shabbat. Carl berättar att namnen i boken är fingerade, men att det var honom som den överlevande (han nämner henne inte vid namn) träffade. Han säger även att han tycker att det är roligt att vara med i en bok. Naturligtvis är det svårt för intervjuaren Brita Johansson att veta vad som sedan står i boken, efter att Carl har slutat läsa. Men faktum är att Hédi Frieds berättelse berör en av de frågor som Britta ställt tidigare till Carl, 


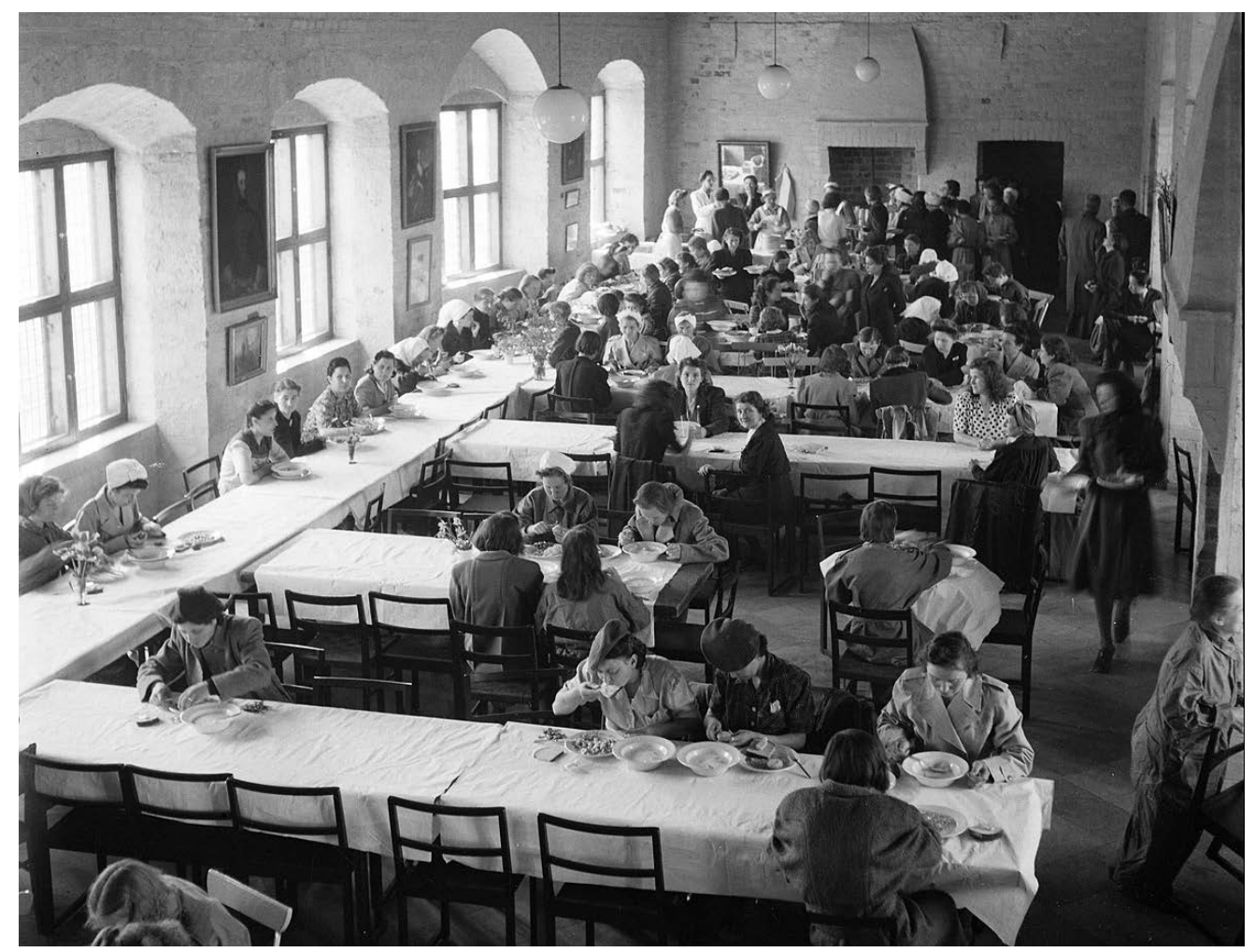

Flyktingar. Folk Bernadottes expedition med de Vita bussarna. Ankomst till Sverige via Helsingborg och Malmö. Matsal. K. W. Gullers 1945-05-01. Nordiska museet (CC BY-NC-ND).

nämligen om det förekom någon kritik mot församlingen. Fried kritiserar inte församlingen i sin självbiografi - men berättelsen fortsätter med att hon berättar om hur middagen blir något av en besvikelse på grund av den språkförbistring som råder och att hon och hennes syster kände sig helt utanför eftersom alla andra gäster talade svenska. Familjen försökte att prata ett språk som alla kunde förstå men utan att lyckas. Fried berättar om middagen med den välbekanta dukningen, ritualen och maten.

Men...Det som vi så starkt hade längtat efter, som vi för några timmar sedan trott oss ha inom räckhåll, samhörighet och en känsla av familjegemenskap hade gäckat oss, alltsammans var återigen långt borta, ouppnåeligt (Fried I 998).
För Carl var mötet med Hédi Fried och hennes syster odelat positivt och han relaterar till det i en samtalskontext där vänskap efterfrågas. För Fried var det ett möte, där glädje (över att bli inbjuden och inkluderad) blandades med sorg (över att det synliggjordes att hon inte hörde till och vad hon hade förlorat). Middagsgästernas oförmåga att inkludera dem i samtalet (trots värdfamiljens försök) förstärkte snarare hennes känsla av att inte längre tillhöra en familjegemenskap. I Svante Hanssons bok finns Hédi Frieds berättelse citerad tillsammans med utdrag från intervjuer med överlevanden som berättar om mötet med "svenska judar". Intervjuerna som Hansson presenterar innehåller liknande berättelser som den som återges i Frieds bok. Hansson menar att "en ofrånkomlig slutsats av intervjumaterialet är, att den svenska 
judenheten bildade ett relativt slutet samhälle, som det var svårt för de överlevande att komma in i och få fotfäste i” (Hansson 2004: 386). Frieds berättelse belyser även språkets betydelse för interaktionen mellan de svenska judarna och flyktingarna. Att fira shabbat utan ett gemensamt språk visade sig vara en sorgfylld upplevelse. Språket och språkförbistringen kan sannolikt ha färgat erfarenheterna av hjälpverksamheten, bidragit till missförstånd, känslor av utanförskap eller upplevelsen av att bli exkluderad även $\mathrm{i}$ andra sammanhang.

David berättar inte heller om något personligt möte eller vänskap med någon flykting eller överlevande. Han berättar istället om att han blev rejält omskakad när han såg filmerna och förstod vidden av det som hade inträffat. I Davids berättelse är således inte mötet med de överlevande något privat, utan i hans redogörelse är hans möte med Förintelsen något som sker på en offentlig arena, på en biograf, tillsammans med flera andra svenskar. Med tanke på att Davids pappa arbetade inom församlingen i Stockholm torde han dock ha hört om och eventuellt även träffat överlevande i hemmet. Detta är dock ingenting som han nämner vid intervjun och ingenting som intervjuaren frågar honom om, vilket kanske indikerar vad Hansson påtalat - nämligen att det var svårt för de överlevande att komma in i den svenskjudiska gemenskapen. Materialet som helhet stödjer även Hanssons slutsats. Förutom Anna är det få som berättar om personliga möten och än färre berättar om längre vänskapsrelationer. Det finns naturligtvis även här undantag. En man som lämnat in sin levnadsberättelse är gift med en överlevande ( $\mathrm{D}_{375}$ : I7).

Materialet i "Judiska minnen" styrker även tidigare slutsatser om att det inom det judiska hjälparbetet i Sverige främst var kvinnor som fick det, oftast oavlönade, uppdraget att praktiskt ta hand om flyktingarna och de överlevande, vilket diskuterats ovan (se även Rudberg 20I5; Thor 20II, 20I9b). Carl berättar inte om några egna möten med de överlevande, trots att han flyttade från Lund och till Stockholm där han arbetade i församlingens kontor. De få berättelser han har om möten med de överlevande handlar i stället om hans mamma som arbetade med mottagningen av de överlevande som kom till Lund. Han berättar i svepande ordalag om att hon var mycket engagerad i hjälp-

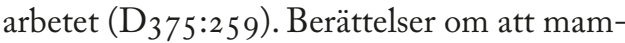
man eller hustrun gick med mat och besökte de överlevande på sjukhus eller flyktingläger förekommer i flera intervjuer och insamlade skriftliga levnadsberättelser i samlingen. En man berättar till exempel om hur hans fru gick med gefilte fish till "de befriade" på epidemisjukhuset i deras stad varje fredag (D 375:293). En kvinna berättar om hur hennes mamma blev kallad till sjukhuset för att ta hand om de sjuka, eftersom hon kunde tala jiddisch. Mamman gick dit varje dag för att tala med de sjuka, men även för att ge dem hemlagad mat ( $\mathrm{D}_{375: 50}$ ). Även denna berättelse belyser, liksom ett flertal andra tidigare refererade berättelser, såväl kvinnornas praktiska insatser som språkets betydelse för den hjälpverksamhet som utvecklades på olika platser och de reella mötena mellan "de svenska judarna" och "flyktingarna".

\section{Avslutande diskussion}

Svante Hansson fastslår i Flykt och överlevnad att det inte går att ge något entydigt svar på frågan om de svenska judarna i allmänhet och församlingen i Stockholm i synnerhet satsade tillräckligt mycket på flyktinghjälp under perioden 1933-1945. Han menar att det går att hävda att hjälpen var otillräcklig och att det säkert fanns betydande hjälpbehov som inte fylldes. Hansson påvisar dock att de svenska judarna var generösa bidragsgivare 
(2004: I68, 4I2). Utifrån intervjuerna som Hansson utförde inom ramen för sitt utredningsarbete menar han att det går att konkludera att den svenska judenheten bildade ett relativt slutet samhälle som det var svårt för flyktingarna, och i synnerhet de överlevande, att få tillträde till (ibid. 386). Hansson lyfter även fram den känsliga relationen mellan "hjälpare" och "hjälpta" och menar att flera av dem som han intervjuade berättade om att de kände sig förödmjukade och otillbörligt behandlade av representanter från församlingen i Stockholm (ibid. 428). Pontus Rudberg har i sin avhandling fortsatt Svante Hanssons arbete och bidragit med fördjupad kunskap om hur församlingen i Stockholm agerade för att hjälpa Europas förföljda judar, främst med utgångspunkt i handlingar från hjälpverksamheten som finns bevarade i den mosaiska församlingens arkiv. Rudberg analyserar främst de sociala strukturer och system som möjliggjorde eller begränsade de svenska judarnas handlingsutrymme. Han fastslår att den svenska statens behandling av judiska flyktingar var mer restriktiv än vad tidigare forskning hävdat vilket starkt begränsade möjligheterna för hur de svenska judarna kunde hjälpa de förföljda i Europa. Rudberg visar även att de svenska judarna gjorde mer för att rädda judarna i Europa än vad tidigare forskning uppmärksammat (Rudberg 2015). Tack vare Hanssons och Rudbergs forskningsinsatser vet vi nu betydligt mer om hur främst den Mosaiska församlingen i Stockholm agerande och vilket handlingsutrymme den hade. Hanssons intervjuundersökning har även gett oss kunskap om hur församlingens agerande kunde upplevas av flyktingarna och de överlevande.

Föreliggande studie kan ses som ytterligare ett komplement till dessa studier då den bidrar med ny kunskap om hur enskilda individer tillhörande den judiska minoriteten i Sverige berättar om hjälpverksamheten under och efter Förintelsen och hur de under I990-talet, när materialet samlades in, och innan någon publicerad forskning förelåg, förhöll sig till den då rådande diskursen om de svenska judarnas förmenta passivitet i relation till Europas förföljda judar.

Det är fyra mycket olika intervjuer som har utgjort den empiriska och strukturerande stommen i denna artikel. I framförallt intervjun med Barbro, som identifierar sig med församlingen i Stockholm, finns ett tydligt tema: försvarsberättelsen. Barbro berättar nästan uteslutande i relation till och för att bemöta den kritik som hon upplever finns i samtiden mot den judiska församlingens agerande. Carl som arbetade vid församlingen som kontorschef i mitten av I940-talet känns dock inte vid någon kritik och bemöter den därför överhuvudtaget inte. Barbro arbetade med flera olika hjälpverksamheter. Carl var anställd med lön för att som kontorschef arbeta med flyktingrelaterade frågor, men omnämner inte några personliga möten med vare sig flyktingar eller överlevande. Barbro arbetade på frivillig basis och försörjdes av sin pappa. Barbros och Carls berättelser, men även andra berättelser i samlingen, styrker således tidigare forskning som synliggjort det judiska hjälparbetets könsarbetsfördelning. Flera inskickade berättelser innehåller redogörelser över kvinnors ofta oavlönade och frivilliga engagemang i såväl flyktingmottagandet som i omhändertagandet av de överlevande. Berättelserna synliggör således det oavlönade, oorganiserade och omvårdande arbete som främst kvinnor utförde under I930- och r 940-talen som exempelvis att ta emot "flyktinggäster" varje kväll vid middagsbordet eller att laga och gå med hemlagad mat till "de överlevande". Analysen av det insamlade materialet i "Judiska minnen" erbjuder därmed en breddad empirisk kunskap om privat och oorganiserat hjälparbete, men även utökade insikter om kvinnors och 
mäns olika initiativ och roller i hjälparbetet.

Anna och David hade aldrig några liknande positioner som Barbro och Carl i relation till hjälparbetet. David är son till en av de framträdande ledarna inom församlingen i Stockholm, men få referenser till pappan, församlingen eller organiserat judiskt hjälparbete förekommer i hans levnadsberättelse. Han berättar inte heller, förutom om familjens "flyktingflicka", om något eget engagemang för eller några personliga möten med flyktingar eller överlevande. Annas levnadsberättelse är däremot full av berättelser om möten med såväl flyktingar som överlevande. Hennes berättelse synliggör därmed vikten av att inte enbart arbeta med församlingarnas eller hjälpkommittéernas arkiv eller blott undersöka församlingsledningens i Stockholm agerande. Anna hade nämligen inte någon insyn eller beslutandemakt över det organiserade hjälparbetet, likväl berättar hon om möten och umgänge med flyktingar och överlevande under sin uppväxt i Kristianstad. Annas berättelse ger oss således helt andra perspektiv på svenska erfarenheter av Förintelsen och det så kallade svenskjudiska hjälparbetet. Intervjun med Anna påminner om att det (judiska) livet inte enbart utspelade sig på församlingsledningens kontor eller i Stockholm utan att mötena mellan flyktingar, överlevande och svenska judar ägde rum även, och kanske främst, i städer och byar långt från församlingsledningen och huvudstaden. Sannolikt är det också så att Anna mötte och umgicks med fler flyktingar och överlevande än exempelvis Carl som arbetade för församlingen i Stockholm under I 940-talet.

Såväl Hansson som Rudberg fastslår att de svenska judarna var generösa bidragsgivare vilket den brittiske forskaren Richard Bolchover (2003) benämner "den filantropiska strategin" i sin analys av de brittiska judarnas svar på Förintelsen och de judiska flyktingarna. Insamlingar lämnar ofta spår i form av upprop och sammanställningar av vad och hur mycket som har samlats in. Olika insamlingsverksamheter har skapat dokument i samtiden och återfinns därmed i exempelvis församlingarnas hjälpkommittéers arkiv. Det är emellertid inte främst berättelser om hjälpaktioner i form av insamlingar som har fått genomslag i det insamlade biografiska materialet. Få personer uppehåller sig vid berättelser om hur pengar eller kläder samlades in i det material som idag utgör samlingen "Judiska minnen". De talar istället om känslor som exempelvis rädslor eller lättnader i relation till händelseutvecklingen i Europa. Därmed synliggörs även att de svenska judarna, framförallt under tidigt r 940-tal, levde med hotet om en nazistisk ockupation av Sverige, och hur det påverkade dem i vardagen. Det insamlade materialet ger även en inblick i det individuella hjälparbete som pågick i flera familjer. Det förekommer åtskilliga berättelser om familjer som tog sig an flyktingar i hemmet, vilket indikerar att det pågick oorganiserade verksamheter som inte alltid har lämnat några dokument efter sig i de judiska församlingarnas eller svenska myndigheternas arkiv. Analysen av berättelserna om flyktinggästerna, flyktingpojkarna och flyktingflickorna synliggör även hur flytande gränsen mellan "dem" (flyktingarna) och "oss" (de svenska judarna) är och att denna uppdelning ibland ändrades över tid. Det som i dåtid var en flykting som familjen tog hand om kan i nutid vara en ingift släkting eller familjemedlem. Några berättelser belyser även att det som den svenska staten eller församlingen definierade som en "flykting", snarare definierades som en släkting av dem som "hjälpte". Därtill finns det uppgifter om att även "flyktingfamiljer" tog emot "flyktingbarn", vilket indikerar att gränsen mellan att vara den som hjälpte eller den som blev hjälpt inte alltid sammanföll med vem som definierades som flykting eller flyktingmottagare/ 
hjälpare. Flyktingarna kunde således vara aktiva i och bidra till hjälpverksamheten (jfr Gatrell 2013).

Det insamlade materialet synliggör även att den judiska befolkningen i Sverige inte, inte ens i Stockholm, var homogen och personers olika erfarenheter och möjligheter att hjälpa under kriget varierade och präglades av plats, ålder, kön och klass. Det kan därför vara missvisande att tala om den svenska judenheten som en gemenskap. Pontus Rudberg understryker att församlingarna i Sverige samarbetade under hela den undersökta perioden och att man sökte lägga personliga eller politiska motsättningar åt sidan. Det stämmer säkert ur ett strukturellt perspektiv, vilket är vad Rudberg (2015) har arbetat med. Men erfarenheten av att leva som jude eller judinna i Sverige under dessa år varierade, vilket de insamlade berättelserna belyser. Personer med östeuropeisk bakgrund, som sökte hjälpa släktingar att komma till Sverige, upplevde sannolikt inte samarbetet på samma sätt som de som företrädde församlingarna och deras olika hjälpkommittéer. Det framgår även av intervjuerna att de som tillhörde de mer väletablerade svenskjudiska familjerna hade större insikter om vad som gick och inte gick att utföra i relation till den politik som fördes av de svenska myndigheterna. De familjer som var nyanlända i Sverige eller som enbart hade levt här i något decennium hade inte samma nätverk eller informationskanaler, men de hade släktingar kvar i Europa. De var därför måhända mer välunderrättade om händelseutvecklingen i Europa, och för dem var hjälpverksamheten därför även personlig. De sökte inte samla in pengar till, hjälpa eller rädda "Europas förföljda judar" utan sina släktingar. Några lyckades och då försörjde de sina släktingar efter deras ankomst till Sverige.

Föreliggande studie har således visat att för att nå fördjupad förståelse av de svenska judarnas agerande och erfarenheter under andra världskriget är det viktigt att utgå från att den svenska judenheten varken var eller alltid agerade som en homogen grupp. Personer handlade inte alltid som representanter för en judisk organisation eller församling utan även som privatpersoner. Genom att använda oral history, i denna undersökning med det insamlade materialet från personer kategoriserade som svenskfödda judar i "Judiska minnen" som empiriskt exempel, synliggörs vikten av att inte homogenisera den judiska befolkningen eller dess agerande. Undersökningen visar även, och framför allt, vikten av att arbeta med flera olika arkiv och källmaterial och hur betydelsefullt det är att historiker synliggör och reflekterar att en viss typ av källor bidrar till en viss typ av empirisk kunskap. När historiker skriver om flyktingarna och flyktingmottagarna i det förflutna bidrar de även till att konstruera berättelserna om dem (jfr Stone 2018:103). Ett sådant problematiserande förhållningssätt till den s.k. svenska judenhetens hjälpverksamhet eller forskningen därom, syftar således inte till att förminska vare sig relevansen av tidigare forskningsresultat eller betydelsen av det hjälparbete som organiserades av de olika församlingarna eller föreningarna, utan bidrar snarare till att synliggöra att hjälpverksamhet kunde bedrivas på flera olika sätt. I citatet som inleder denna artikel menar mannen att: "Kontoret, min egen familj och släkt - familjen tog all min tid. Det fanns ingen tid över. Det blev således ingen tid för det judiska.” Jag skulle snarare vilja påstå, med stöd i materialet som utgör "Judiska minnen", att mannen i likhet med flera andra svenska judar (men även judiska flyktingar) under kriget och Förintelsen ägnade en stor del av sin fria tid åt det "judiska" (hjälparbetet) dock inte enbart i församlingarnas regi, utan även och kanske lika ofta i privat regi och efter eget initiativ. 
Malin Thor Tureby är historiker vid Institutionen för samhälle, kultur och identitet (SKI) vid Malmö universitet. Hösten 2019 och våren 2020 var hon förordnad expert inom utredningen om ett museum om Förintelsen (Ku 20019:01). Thor Turebys forskning rör sig i skärningsfälten mellan Holocaust studies, judisk historia, migrations- och

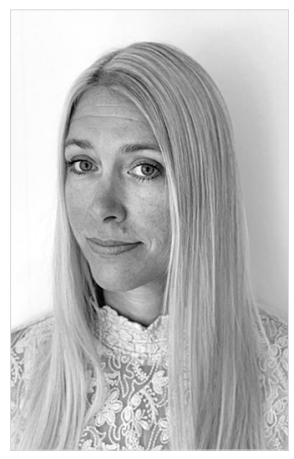
minoritetsstudier. Hon är särskilt intresserad av metodologiska frågor som berör kulturarv, arkiv och samlingar, oral history samt forskningsetik. Bland hennes senaste publikationer kan nämnas "Memories, testimonies and oral history: on collections and research about and with Holocaust survivors in Sweden", i Holocaust Remembrance and Representation: Documentation from a Research Conference (se Thor Tureby 2020) och Migration och kulturarv. Insamlingsprocesser och berättelser om och med de invandrade ca 1970-2019 (Nordic Academic Press, 2020).

\section{Källor och litteratur}

\section{Källor}

Nordiska museets arkiv, Stockholm

Samlingen Judiska minnen

Levnadsberättelser: $\mathrm{D}_{375}: 8, \mathrm{D}_{375}$ : I3-I4,

D $375: 17-18, D_{375: 23}, D_{375: 42}, D_{375: 46}$,

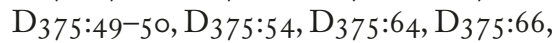

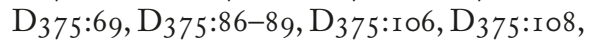

D 375 :I I I, D 375 : I 54, D 375 : I 74, D 375 :I92,

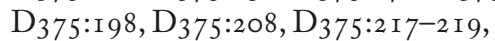

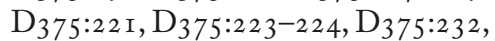

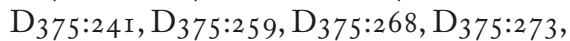

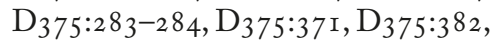

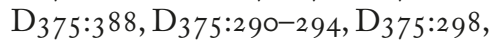

D375:301.

\section{Litteratur}

Bergoffen, Wendy H. 2or 6. "Taking care of our own: narratives of Jewish giving and the Galvestone Movement", Shofar: An Interdisciplinary Journal of Jewish Studies, 34(2): 26-58.

Bolchover, Richard. 2003. British Jewry and the Holocaust: With a Nerw Introduction, (Cambridge: The Littman Library of Jewish Civilisation).

Dahl, Izabela A. 20r 8."Att göra skillnad. Ingrid Segerstedt Wibergs hjälpverksamhet för flyktingmottagande i Göteborg under andra världskriget”, i Allvarligt talat: Berättelser om livet, red. Maria Sjöberg (Göteborg: Makadam Förlag), 4I 9-434.

Fried, Hédi. I 998. Livet tillbaka (Stockholm: Natur och kultur).

Församlingsblad för Mosaiska församlingen i Stockholm, augusti 1947.

Garde, Pia-Kristina. 2004. De dödsdömda vittnar. 60 år senare (Bromma: Megilla förlag).

-2008. Mina föräldrars kärlek (Strängnäs: Axplock).

Gatrell, Peter. 2013. The Making of the Modern Refugee (Oxford University Press).

2016."Refugees: what's wrong with history? Journal of Refugee Studies 30(2): I70-I 89.

Gottfarb, Inga. I 986. Den livsfarliga glömskan (Höganäs: Wiken).

Hansson, Svante. 2004. Flykt och överlernad. Flyktingverksambet i Mosaiska forrsamlingen i Stockholm 1933-1950 (Stockholm: Hillel förlaget).

Hermele, Bernt. 20 1 8. Kommer de, så skjuter jag oss. Om svenska judars liv i skuggan av förintelsen (Stockholm: Lind \& Co).

Lomfors, Ingrid. I 996. Förlorad - àtervunnet liv. De judiska flyktingbarnen frän Nazityskland (Göteborg: Historiska institutionen).

Marfleet, Philip. 2007."Refugees and history: why we must address the past", Refugee Survey Quarterly, 26(3): I36-I 48.

Olsson, Lars. I995. På tröskeln till folkhemmet. Baltiska flyktingar och polska koncentrationslägerfängar som reservarbetskraft i skånskt jordbruk kring slutet av andra världskriget (Lund: Morgonrodnad).

Rubinstein, Harry. I 97 I. Mosaiska forrsamlingen i Malmö 100 år, 1871-1971 (Malmö: Församlingen).

Rudberg, Pontus. 201 5. The Swedish Jerws and the Victims of Nazi Terror, 1933-1945 (Uppsala: Acta Universitatis Upsaliensis).

Sarna, Jonathan D. I 995. "What's the use of local Jewish history", Rhode Island Jewish Historical Notes, I2(I): 77-83.

Segerstedt Wiberg, Ingrid. 1980. ”Från förintelsens tid", i Göteborgs mosaiska församling. 1780-1980. Minnesskrift till Göteborgs mosaiska församlings 200-årsjubileum (Göteborg: Kyrkbyns Boktryckeri), I 43-I 55 .

Sterner Carlberg, Mirjam. 1994. Gemenskap och överlevnad. Om den judiska gruppen i Borås och dess historia (Göteborg: Institutionen för socialt arbete). 
Stone, Dan. 201 8."Refugees then and now: memory, history and politics in the long twentieth century: an introduction", Patterns of Prejudice, 52(2-3): Io I-Io6.

Tegen, Gunhild, och Einar Tegen. I 945. De dödsdömda vittna. Enquêtesvar och intervjuer (Stockholm: Wahlström \& Widstrand).

Thor, Malin. 2005. Hechaluz - en rörelse i tid och rum. Tysk-judiska ungdomars exil i Sverige 1933-1943 (Växjö University Press).

— 2006."'...en, efter förhållandena utmärkt tillvaro...'. De danska flyktingarna, arbetsmarknadskommissionen och hjälpkommittén för danska flyktingar i Kalmar I 943", i Flervetenskapliga perspektiv i migrationsforskning, red. Katarina Hjelm (Växjö University Press), I I 3 -I 28 .

_ 2008. "Svallvågorna av katastrofen kom också till vår stad'. Hjälpverksamhet inom Norrköpings mosaiska församling i skuggan av Förintelsen”, i En problematisk relation? Flyktingpolitik och judiska fyktingar i Sverige 1920-1950, red. Lars M. Andersson och Karin Geverts Kvist (Uppsala, Opuscula historica Upsaliensia), I 79-207.

—_ 2010."På tröskeln till Kalmar. Kommittén för flyktinghjälp, den mosaiska församlingen och flyktingarna i Kalmar 1 945-1 946", i Sambällshistoria i fokus. En festskrift till Lars Olsson om arbete, migration och kultur, red. Lars Berggren et al. (Malmö: Big Bad Books), I 93-2II.

_-20г r."Gemenskapens förutsättningar och gränser. En intersektionell analys av'judisk' flyktingverksamhet i Sverige under I930- och I 940-talen", i Judarna i Sverige - en minoritets historia, red. Helmut Müssener, Uppsala Multiethnic Papers, 53 (Uppsala universitet), 99-I 24 .

Thor Tureby, Malin. 2013a."To hear with the collection: contextualisation and recontextualisation of archived interviews", Oral History, 4I (2): 64-73.

2013b. "The Swedish Jews and the Jewish survivors: the first public narratives about the survivors in Swedish-Jewish press", i Reacbing a State of Hope, red. Mikael Byström och Pär Frohnert (Lund: Nordic Academic Press), I 45-I64.

_or ga. "Svenskjudiska liv. Levnadsberättelser i skuggan av Förintelsen", Svenska landsmål och svenskt folkliv. Tidskrift for talspråksforskning, folkloristik och kulturbistoria, I4I: I I 7-I 44. —_or gb.”Den Judiska Kvinnoklubben (JKK) och de judiska flyktingarna under I 930- och I 940-talen", Nordisk Judaistik, 30(2): 3-26.

_or 9c."Makten över kunskapsproduktionen.

Den institutionaliserade etikprövningen och humanistisk och kulturvetenskaplig forskning", Kulturella perspektiv. Svensk etnologisk tidskrift, 28( I-2): I 7-29.

-2020."Memories, testimonies and oral history: on collections and research about and with Holocaust survivors in Sweden", i Holocaust Remembrance and Representation: Documentation from a Research Conference, SOU 2020:2 I. (Swedish Government Official Reports), 67-92.

2020 (uu)."The Holocaust and the Jewish survivors in the Swedish-Jewish press, I 945 to I955", i The Early Holocaust Memory in Sweden. Archives, Testimonies and Reflections (prel. titel), red. Pontus Rudberg och Johannes Heuman (Palgrave Macmillan).

Torvinen, Taimi. I 989. Kadimah. Suomen juutalaisten historia (Helsinki: Otava). 